\title{
Opening the Door: How the Regional Autonomy Has Made the Implementation of Perda Sharia Possible?
}

\author{
Erwin Nur Rif'ah'1 \\ ${ }^{1}$ Jember Islamic University, East Java Indonesia \\ Email: erwinnur2@yahoo.com \\ Phone: +6287876050153
}

\begin{abstract}
Sharia-influenced regional regulations (perda sharia) are regulations or laws that are created by district governments and use Islamic moral teachings as a reference point. This article based on a qualitative research in two districts: Cianjur, West Java and Bulukumba South Sulawesi. In general, perda sharia seeks to manage three aspects of public life: firstly, to eradicate moral and social problems such as prostitution, drinking alcohol and gambling; secondly, to enforce ritual observances among Muslims such as reading the Qur'an, attendance at Friday prayers and fasting during Ramadan, and thirdly, to govern the way people dress in the public sphere, especially in relation to head-veiling for the women.
\end{abstract}

Keyword: Regional Autonomy, perda sharia, regional regulations

\section{A. INTRODUCTION}

Although Indonesia is a country with the largest Muslim population (Porter 2002), it has never been led by someone who has supported the establishment of a state with an Islamic constitution. Since Indonesian Independence, all efforts to establish an Islamic state in Indonesia have failed. However, since the fall of Soeharto in 1998, particularly after the Habibie government passed two laws on regional autonomy, many districts implemented sharia-influenced regional regulations (perda sharia). By definition, Sharia-influenced regional regulations (perda sharia) are regulations or laws that are created by district governments and use Islamic moral teachings as a reference point. In general, perda sharia seeks to manage three aspects of public life: firstly, to eradicate moral and social problems such as prostitution, drinking alcohol and gambling; secondly, to enforce ritual observances among Muslims such as reading the Qur'an, attendance at Friday prayers and fasting during Ramadan, and thirdly, to govern the way people dress in the public sphere, especially in relation to head-veiling for the women (Azra \& Salim 2003; Bush 2008b; Candraningrum 2006).

This article tries to answer the questions of: what has made Perda Sharia possible? What is the relationship between Perda Sharia and regional autonomy? To what extent have the regional autonomy laws made Perda Sharia possible? On the history of the issue of sharia, and how the issue of sharia has been debated in Indonesian politics. This explanation then followed by the discussion on the Soekarno and Soeharto policies toward Islam, which continued with the discussion on the duality policies of Soeharto toward Islam. The third section will be discussion on the reformation era which started after the resignation of Soeharto in 1998. This part also explains the political changes as an impact of the resignation of Soeharto, who was succeeded by B.J. Habibie as President. The next part will be the discussion on the relation between regional autonomy and Perda sharia, and how the regional autonomy law make the implementation of 
Perda Sharia possible. The debate on the implementation of perda sharia will be discussed in the fifth section. The last part discusses the politics of nomenclature of perda sharia.

\section{B. METHODOLOGY}

This article based on a qualitative research in two districts: Cianjur, West Java and Bulukumba South Sulawesi. To answer these questions; what has made Perda Sharia possible? What is the relationship between Perda Sharia and regional autonomy? To what extent have the regional autonomy laws made Perda Sharia possible? The article begins with the exploration.

\section{RESULT AND DISCUSSION}

\section{The History of Sacred Word of Sharia in Indonesian Politics}

The issue of Sharia has become a sensitive issue in Indonesia. And the struggle to implement Sharia Islam has involved long and bitter debates, particularly because its aim is to establish a formal basis for state power. In the months before the proclamation of Indonesian independence, Muslim leaders who became members of the Preparatory Committee for Indonesian Independence (BPUPKI-Badan Penyelidik untuk Persiapan Kemerdekaan Indonesia) had to struggle to introduce, in the preamble of the 1945 constitution, a phrase that would obligate all Indonesian Muslims to perform their religious duties (Boland 1982). The preamble, later known as the Jakarta charter, which includes the seven words "dengan kewajiban melaksankan Sharia Islam bagi pemeluknya" (with the obligation to carry out Sharia for its adherents), would provide a constitutional basis for the enforcement of sharia in Indonesia. However, the inclusion of these seven words into the constitution was unsuccessful, mainly because it was strongly opposed by the minority non-Muslim politicians and the secular nationalists, most of whom were also Muslims (Azra \& Salim 2003; Boland 1982; Halim 2005).

Apart from the formal effort through political institutions such as MPR, another campaign to implement Sharia Islam was also conducted through rebellions. In 1948 the leader of Darul Islam rebellion movement, S.M Kartosuwiryo, declared an independent Islamic state in West Java, in which Islamic law would be strictly implemented. By the early 1950s, militant Muslims in other provinces, including Aceh, South Sulawesi and South Kalimantan, had joined the Darul Islam. However, these struggles never succeeded in achieving their goal (Asi 2007).

In 1959, the debates on the implementation of Sharia were renewed in the Constituent Assembly during the debates about a new Constitution. Again, during the debates, the Muslim Political Elites demanded that the Sharia principles be clearly stipulated in the new constitution. The idea was again strongly rejected by the secular nationalists, most of whom were Muslim and non-Muslim nationalists. When the debate became irreconcilable, President Soekarno issued a decree on 5 July 1959, which declared that the Constituent Assembly (Majelis Konstituante) was dissolved and he restored the 1945 constitution. He argued that the Jakarta Charter was not necessary because of the way it had inspired the 1945 Constitution. However, the debate was unresolved. From 1959 onward, the Jakarta Charter remained a divisive issue between the secular nationalists and the Islamic groups, within Indonesian societies (Boland 1982; Hooker 2003; Mujani 2007; Ricklefs 2008, pp. 301-3).

The debate on the Jakarta Charter persisted in the early years of the New Order government, particularly when the Islamic parties again demanded the government insert the Jakarta Charter as an integral part of the preamble to the 1945 Constitution. Nevertheless, this endeavour failed 
because the army, which during the New Order government also functioned as a strong political base for President Soeharto, could not tolerate such an issue being discussed in the MPR session of 1966-1967 (Boland 1982).

The New Order regime of President Soeharto remained in power until 1998 and during his administration, the Sharia issue had no chance to be raised in any session of the parliament, which was dominated by the military, the ruling party, Golkar and government officials. However, although the Jakarta charter was not accepted by the Soeharto government as part of the 1945 constitution, a number of laws containing Sharia influence were enacted such as the marriage law, waqaf (charitable foundation) regulation, the religious court law, the law that allows the operation of Islamic banks and the codification of Islamic law that includes the rules of inheritances. Furthermore, President Habibie added two laws that covered the administration of hajj and zakat. However, all elements of Islamic law that have been integrated into national law are mainly the result of political interaction between the Indonesian Government and the Islamic communities, particularly the Muslim elite (Azra \& Salim 2003). And all these laws that accommodate some elements of Islamic Sharia have been enacted without any reference to the Jakarta Charter.

\section{Contrasting Soekarno and Soeharto's Policies toward Islam}

Political Islam, has experienced many disadvantages both during Soeharto government and when Soekarno was President. Soekarno promoted Nationalism as a dominant political philosophy and political Islam was subjected to various countervailing forces. Pringle (2010, pp. 68-9) noted that there were six key episodes of the Soekarno era that shaped political Islam. The first was the dispute over the Jakarta Charter in 1945; the second was the communist-led Madiun affair in 1948; the third were the Darul Islam uprisings, 1948-1962; the fourth was the outer Island Rebellion in 1957-1958; the fifth was the attempted coup and communal killings of PKI in 19651966 and the last one was the election of 1955 which was the first democratic polling in Indonesia's history and remains an important indicator of political Islam's strength in the early days of the Republic. Apart from that, in 1960 Soekarno banned PSI and the Reformist Islam Party: Masyumi, as a consequence of their resistance to guided democracy and for complicity in the Outer Island Rebellion (Pringle 2010, p. 89). NU and Masyumi were much more successful in the 1955 elections than Islamic parties have been in the post Soeharto elections.

Sukarno's abolition of parliamentary democracy and its replacement by his authoritarian Guided democracy abolished as political system that was supportive of Islamic political aspirations. Sukarno's policies towards political Islam had much in common with Soeharto's in that the objective of both was to contain the influence of political Islam. In addition, Sukarno promoted national unity through NASAKOM, an acronym for the three major ideological streams in Indonesian politics: Nasionalisme (nationalism), Agama (religious) and Komunis (communism), an effort to blend nationalism, communism and religion (including Islam) into national ideology (Pringle 2010, pp. 68-9). What Soekarno's ideology of NASAKOM apparently meant was that PNI for nationalism, NU for religion and PKI for communism, should share a role in government at all levels, thus producing a system which would rest upon a coalition of predominantly Java-based political forces. The important aspect of NASAKOM from the perspective of political Islam was that Islam, through Agama, was accommodated in this ideological formulation, but not given a special place.

Soeharto realised that the Sukarno's failure due to his focus on ideology and political affairs, which resulted in a never-ending tension between religious groups and the state, so, Soeharto decided to focus on strategy of development and modernization (Hasan 2008, p. 25). In the early days of 
Soeharto presidential, he considered the communist party to be the number one threat followed by political Islam, especially the reformists (Pringle 2010, p. 85). However, Soeharto adopted 'Snouck Hurgronje's ideas regarding Islam and the state influenced that approach of the New Order government, which displayed respect for Islam as private religious practice but was determined that Islam should not become a powerful political force (Ricklefs 2008, p. 322). Soeharto implemented 'duality policies' toward Islam: political Islam was marginalised and repressed, while what the government thought were religious, educational and cultural and not political activities were supported. Consequently, religious expressions were marginalized in the political process, in spite of the considerable role that was played by Muslims in bringing the New Order into existence. Toward the end of his rule, in order to maintain power, Soeharto began to court hard-liner Reformist proponents of Islamic fundamentalism in order to divide and defeat a growing prodemocracy movement, which included new politically liberal Muslim elements (Pringle 2010, p. 85).

For more than 30 years under the New Order regime (1966-1998), the Soeharto government ruled Indonesia through centralism and authoritarianism. As a result, there were many restrictions including those placed on participation by local government or citizens in public agendas, decision making or in the evaluation and implementation of government's policies (Erawan 2007, p. 65). The government tightly controlled the society, ensuring that all decisions were made by and served the interest of the central government. During the Soeharto government, the regional aspirations were largely unexpressed and discouraged. Democratic institutions and practices were absent, while civil society was virtually non-existent (Turner et al. 2003b, p. 11).

\section{The Duality in Soeharto's Policies toward Islam}

At the early period of Soeharto's rule, under the influence of two main advisers, Ali Murtopo and Sujono Humardani, Soeharto resisted any revitalization of political Islam and controlled political Islam. For instance, Masyumi, which was placed second in the 1955 general election, then banned by Soekarno in 1960, was not permitted to re-establish itself. Instead, a new party, Parmusi, without the leadership of former Masyumi leaders, was established to accommodate Muslim modernists. As a result of the intervention of the Soeharto government in the internal affairs of the party, the new party failed to attract votes in the general election of 1971. Other Islamic Parties also failed to counter the emergence of Soeharto's Golkar party, which obtained 62.8 percent of the total votes (Bruinessen 1996b; Hasan 2008, p. 25).

After Golkar's victory in the general election of 1971, Soeharto intensified marginalization toward political Islam by applying a policy of 'fusion of the party'. This policy requires all Islamic parties to coalesce into one, the Partai Persatuan Pembangunan (PPP - United Development Party), whereas nationalist and Christian parties were incorporated into the Partai Demokrasi Indonesia (PDI Indonesian Democratic Party). To support his policy, Soeharto popularized development jargon and imposed the Pancasila as the state's governing doctrine (Ricklefs 2008, p. 355). Any aspirations to challenging the Pancasila can easily be labeled either 'extreme left' or 'extreme right', and anti-Subversive laws, inherited from Sukarno were used by the state to justify the method (Hasan 2008, p. 25). Through an indoctrination program called 'Pedoman, Penghayatan dan Pengamalan Pancasiala (P4-Guide Understanding and Practice of Pancasila) and other instruments, Pancasila was systematically embedded in the minds of citizens of Indonesia (Hasan 2008, p. 26).

Moreover, New Order also tried to domesticate the social forces of Ulama (Islamic scholars), by proposing the establishment of a semi-governmental body: Majelis Ulama Indonesia (MUI - 
Indonesian Ulama Council), in order to strengthen its hegemony over society and to extend its power and control. This council was assigned the issuing of religious legal opinion (fatwa) and advice on religion (tausiyah). This idea was made public during a national conference of Muslim preachers in 1970 held by Pusat Dakwah Islam Indonesia (Indonesian Islamic Propagation Centre), an institution established by the Ministry of Religious Affairs. However, MUI was not established immediately, partly because of criticism from some participants, particularly Hamka, a leading modernist scholar. Hamka saw that the endeavour of the council of Ulama was intended to mobilize support of one Islamic party that leading the Department of Religious Affairs from other groups to maintain its power (Hosen 2004, pp. 149-50). Thus the council would only issue fatwas from that party which would only satisfy people from that party but not all Muslim (Hosen 2004). Then in 1974, the Pusat Dakwah Islam once again held a conference for Islamic preachers, which concluded that it was necessary to establish a council of ulama, which was strong supported by President Soeharto. Soeharto insisted on the need for a national body of ulama that could serve as, among other functions, as a mediator between the government and the ulama and the broader community. The government hoped that the MUI would explain and endorse its development policies (Ichwan 2005).

However, in 1973, Professor Mukti Ali, who had a close relationship with modernist Muslims and the Muhammadiyah to which Hamka belonged, was appointed as a minister of religious affairs (Hosen 2004; Kementrian Agama Republik Indonesia 2011). Therefore, in 1975 Hamka supported the establishment of the MUI (Hosen 2004). Finally, the Majelis Ulama Indonesia was officially established during a national conference of Ulama that was held on 21-27 July 1975. The first General Chairman of the MUI (1975-1981) was Professor Hamka, who had earlier rejected the idea of such a council (Hosen 2004, p. 150).

The MUI was also expected to be representative of Muslims in inter-religious dialogue, a project launched by the Mukti Ali, to build what was often referred to as the 'harmony of religious life', namely, peaceful coexistence of religious groups (Mujiburrahman 2006). The nature of the Majelis Ulama Indonesia as a creation of the government was immediately visible. It was involved in polemics and issued a number of (controversial) fatwa legitimizing government policies (Mudzhar 1993).

Furthermore, Soeharto's efforts to obstruct access to power by the Islamic political forces triggered armed resistance in the name of Islam. The rebellion, including by groups called Komando Jihad (Jihad Commando), led by Ismail Pranoto carried out bomb attacks in Java and Sumatra; another, led by Abdul Qadir Djaelani and calling itself 'Pola Perjuangan Revolusioner Islam' (Islamic Revolutionary Struggle Model), stormed the building of Majelis Permusyawaratan Rakyat (MPR People's Consultative Assembly) during the general assembly in March 1978. No less important is a series of murders and robberies committed by a group of radicals led by $\mathrm{M}$ Warman, known as 'Terror Warman'. Another group, led by Imran M Zein, attacked a number of government facilities, which culminated in the hijacking of a Garuda Indonesia plane on March 28, 1981. The veterans of the West Java-based Darul Islam, which initially had been hired by Murtopo's intelligence service to combat communism, led other attacks to revolt against Soeharto and establish an Islamic state (Santosa 1996; van Bruinessen 1996, 2002). However, Soeharto remained unaffected and was able to suppress and marginalise them.

After the Tanjung Priok incident on September 12, 1984, in which at least 20 people were killed and more than fifty demonstrators were injured, Soeharto announced a Bill on the Mass Organizations and Political parties, which required all political parties and mass organizations to accept Pancasila as 'asas tunggal' (the sole ideological basis of the state), so that, Islam was 
prohibited from being used as the ideology for any organizations. In reaction to this policy, NU (Nahdlatul Ulama), Indonesia's largest organization of traditionalist Muslims, quickly declared its acceptance of Pancasila, but Muhammadiyah, a modernist-Muslim organisation, took some time to accept the inevitable. (Ismail 1995).

\section{Soeharto's Accommodating Policies toward Islam}

In the late 1980s, Soeharto began to introduce policies to accommodate Islam, focusing mainly on promoting Islamic symbols in public discourse. For example, the Directorate General of Primary and Secondary Education, issued a new regulation on student uniforms, and lifted the ban on female students wearing the hijab (headscarf) in schools. Soeharto himself and his family went to Mecca to perform the hajj in 1991. Upon his return from Mecca, Mbak Tutut, Soeharto's eldest daughter and a popular figure, began to show her piety in public by wearing a colorful, elegant veil. The model she presented and the way she wore her headscarf gave a prime example to the entire nation. Since then, members of the cabinet and senior officials no longer hesitated to use the Islamic greeting, Assalamu'alaikum, to open a speech, and the greeting has been becoming increasingly popular. They also tried to show their concern with the Islamic affairs as an example, participating in religious festivals and celebrations. In this context, Islam was systematically accommodated in the discourse of the state to offset the increasing number of challenges to the legitimacy of Soeharto's political leadership (Hasan: 2008).

Therefore, a number of organizations, institutions and activities that identified with Islam and utilised Islamic symbols began to appear, including the Ikatan Cendekiawan Muslim Indonesia (ICMI - Indonesian Muslim Intellectual Association), led by B.J.Habibie and established under the patronage of Soeharto (Bruinessen 1996a; Hefner 1993). The ruling party, Golkar, started to be more accommodating of Islam and involved Muslim intellectuals more. In addition, thousands of mosques were built under the sponsorship of the state. Furthermore, the Religious Court Bill was introduced, followed by a Presidential Decree on the Compilation of Islamic Law. In the economic aspect, The Bank Muamalat Indonesia, which has as a slogan: 'pertama sesuai sharia' (the first [bank in Indonesia] in accordance with the sharia), was established and its establishment initiated the mushrooming of Islamic sharia banks and insurance companies (Möller 2005). However, Soeharto's accommodation of political Islam with ICMI (Ikatan Cendekiawan Muslim Indonesia Indonesian Muslim Intellectual Association) was merely support for Islamic religion, culture and education, but did not support a greater political role. In this respect, Soeharto had not departed from Dutch colonial policies. No doubt, these policies were part of Soeharto's political strategy to hold onto power (Liddle 1996). Apart from the changes in Soeharto's attitudes and policies towards political Islam from the late 1980s, there was also a change in Islamic beliefs and practices. Islamic revivalism reflects the influence of the Iranian revolution, Saudi money and the emergence of better-educated Muslim elite. Broader changes in society were occurring despite and because of government policies.

\section{Reformasi, and changes in Indonesian Politics}

The resignation of Soeharto on 21 May 1998 opened a great opportunity to change the political system and government. Many of those who demonstrated for Soeharto's resignation demanded that the Constitutional be amended. The amendments sought included the recognition of the Jakarta Charter. In addition, demands for democracy, characterised by a free election, freedom of press, and nation-wide call for 'reformasi' were unavoidable. This also gave the opportunity for the regional government, especially regions rich in natural resources, to demand that the central government decentralise its authority and function. 
Habibie, the successor of Soeharto, according to Aspinal and Fealy (2003), wanted to dissociate himself from the Soeharto regime, Although Habibie was Soeharto's longest serving minister and last vice President. His government made some significant changes such as: revoking laws on restricting the numbers and activities of political parties; holding a relatively free parliamentary election in 1999; and enacting regional autonomy laws.

The decentralisation of governmental authority was one of the most important reform programs in Indonesia (Erawan 2007, p. 55). The decentralisation policy in Indonesia was based on the Regional Autonomy Law No. 22, concerning regional Government, and Law No. 25, 1999 concerning The Financial Balance between the Central and Regional Government (Turner et al. 2003b, pp. 15-6). Both these laws were based on five principles: 1. democracy, 2. community participation and empowerment, 3. equity and justice, 4. recognition of the potential and diversity within regions, and 5 . the need to strengthen local legislatures. These five principles were in line with the spirit of reformasi (Turner et al. 2003b, p. 23; Usman 2002) to ensure that regional autonomy in Indonesia is in line with the principle of democratisation, such that people in subnational territories (province, district and municipality) are given significant decision-making powers. These require devolution of authority from central government to sub-national political institutions that are accountable, responsive, and representative of their local communities.

The significant feature of these laws is that there was no clear hierarchy between district (kabupaten) and municipality (kota) governments and the provincial government. The regional government was made responsible to the DPRD (Dewan Perwakilan Rakyat Daerah-Regional Peoples' Representative Assembly) rather than to the authority of central government in Jakarta. However, although the authority of regional government significantly became stronger after the implementation of Regional Autonomy Laws, the central government still has considerable authority by controlling the regional authority such as on health and education. Nevertheless, the function and the authority of the DPRD have become considerably more important. (Turner et al. 2003a, pp. 24-64).

\section{The Regional Autonomy and Perda Sharia}

The resignation of Soeharto was followed by the euphoria for democracy and political liberation, especially among many Muslim groups. As William Liddle (Liddle 1996) predicted, there would be more demands for a more formalistic Islam (the scripturalists) due to the open political climate, since 'they would have many more political resources, in mass acceptance of their ideas, organization, allies, media and access to politicians'(Liddle 1996 p. 13). Firstly, this was reflected in the establishment of many Islamic political parties that mostly replaced Pancasila with Islam as the ideology the organisation. Secondly, there was a growing demand from many regions to formally implement sharia. The third was the emergence of Muslim groups considered by many as Radical groups, such as the Laskar Jihad (Holy War Fighters), The Front Pembela Islam (FPIIslamic Defenders Front), Hizbut Tahrir Indonesia (HTI- Indonesian Liberation Party), Laskar Jundullah and Majelis Mujahidin Indonesia (MMI- Indonesian Mujahidin [the Jihad Fighter] Council). Finally, Sabili, an Islamic (hardliners) magazine, became very popular. According to a survey conducted by AC Nielsen, had the second largest circulation for a magazine (Salim, Arskal \& Azra 2003b). This weekly magazine which was published underground during Soeharto era, used to be a dakwah (call for Islam) newsletter, but it is now appearing to promote political Islam, typically from the hardliners' point of view. Some of their opinions were advocating support for the formal application of Sharia in Indonesia (Salim, Arskal \& Azra 2003a, pp. 1-2). 
Many scholars, such as Fealy (2005), Riddell (2005), Salim and Azra (2003b), argue that the fall of Soeharto in May 1998, created a greater opportunity and freedom for Muslims groups to incorporate more Sharia Islam elements into Indonesian legislation. There were greater demands for the implementation of Sharia in several regions in Indonesia, especially when Habibie's government passed two laws to introduce regional autonomy. However, the formal application of Sharia-influenced regulation in Indonesia was possible only because some factors. The first factor is when the People Consultative Assembly (Majelis Permusyawaratan Rakyat - MPR) amended several Articles of the Constitution in August 2000, including Article 18 which provided a constitutional basis for the regional autonomy laws, through which districts and municipalities were given the authority to manage their own affairs (Ellis 2007, pp. 22-33). However, the Constitution outlines that the regional autonomy has to be implemented within the framework of Indonesia as a unitary state, which recognizes ethnic, cultural and religious diversity.

Based on the regional autonomy laws No 22/1999 and Law No 25/1999, the central government must concede authority to the regional government in all fields excluding foreign policy, defence and security, monetary and fiscal policy, the legal system or judicature, and religious affairs. In addition, the central government also maintains control of its specific functions such as national planning, setting and the supervision of technical standards. Therefore, the regional governments, whose power previously had been strictly limited, now has to take full responsibility for many important areas such as education, health, the environment, labour, public work and natural resource management (Aspinall \& Fealy 2003; Turner et al. 2003a, pp. 24-5).

The second is after the central government granted Aceh with special autonomy. Although it is clearly stipulated in the Regional Autonomy Law that regional governments do not have authority on religious affairs, numerous regions insisted on implementing Sharia-influenced regional regulations. The situation became more complicated with the Special Autonomy Law for Nanggroe Aceh Darussalam (Law 18/2001), which gave jurisdiction to the province to implement Sharia law (Halim 2005). Many other provinces and districts including South Sulawesi, two districts in West Java (Cianjur and Tasikmalaya), Banten, West Sumatra and South Kalimantan sought powers similar to those granted to Aceh in order that Sharia Islam can be implemented. However, without the broader powers granted to Aceh, many districts issued regional regulations (perda), decrees (keputusan), instructions (instruksi) and circulars (surat edaran) that reflected Islamic values, teachings and injunctions. These regulations are concerned with three aspects. The first is public order and social problems such as prostitution, consumption of alcohol and gambling. The second is religious skills and obligations such as reading the Qur'an, attending Friday prayers and paying zakat. The third is related to religious symbolism including Muslim dress (Salim, A. 2007).

South Sulawesi was probably the most determined province in its desire to implement Sharia Islam. Abdul Azis Kahar Muzakkar, chief of the Preparatory Committee for the Islamic Sharia Enforcement (Komite Persiapan Penegakan Sharia Islam-KPPSI), who is also the son of the leader of the Darul Islam rebellion in South Sulawesi, argues that the special autonomy granted to Aceh, including the implementation of Sharia, has paved the way for other Indonesian provinces to demand the same status (Mudzakkar 2010).

The third factor was the failure at the national level to implement sharia Islam. For instance the two Islamic parties: United Development Party (Partai Persatuan Pembangunan-PPP) and Crescent Star Party (Partai Bulan Bintang-PBB) campaigned for inclusion of the Jakarta Charter in Article 29 clause 1 of the 1945 Constitution, which is the clause that stipulates the theological foundation of the nation. By the inclusion of the Jakarta Charter, they hoped that it would officially provide sharia with the constitutional status within the Indonesian national legal system. This proposal was not 
adopted in three consecutive annual sessions of MPR in 2000, 2001 and 2002, despite the very strong demand by formalist Islamic Parties such as PPP, PBB and PKS, formalist Islamic groups such as HTI (Hizbu Tahrir Indonesia-Indonesian Liberation Party), Majelis Mujahidin Indonesia and KAMMI (Kesatuan Aksi Mahasiswa Muslim Indonesia). However, the amendment was opposed by substantive Islamic Parties such as PKB, PAN as well as secular parties such as GOLKAR, PDI$P$, the Christian parties and many NGOs. Subsequently, the formalist Islamic parties and some other Islamic groups continued to campaign for sharia in provinces, districts and municipalities through regulations inspired by Islamic Sharia (Halim 2005; Salim, Arskal \& Azra 2003b) .

Thus, regional autonomy has opened opportunities for the implementation of Sharia-influenced regulations after the many failures to implement sharia law since1945 at the national level. A number of factors help explain this change such as the foundations of the law of Perda Sharia are different from the idea to implement sharia at national level. The supporters could use different reasons to implement Perda Sharia such appealing to local cultural values, the need to maintain social order and security, whereas the objective of the implementation of Sharia at national level was to obtain formal status for sharia as part of the national constitution which many considered as a threat to Indonesian unity. Apart from that, the regions that implement Perda Sharia are regions with majority Muslim populations, so they have the 'legitimacy' to implement Islamic-influenced regulations for 'reasons', relating to local aspirations and democratic support. At national level, Sharia could be considered as simply discrimination against the non-Muslim population. Although Muslims are the majority population in Indonesia as a whole, however the non-Muslim communities are often located in particular regions and islands where they form substantial minorities or majorities. Implementing sharia in these regions might be a trigger for disintegration. in addition, at the national level, any legislation needs the support of majorities in both houses of parliament where many members are not Muslim, However at the regional level, , the DPRDs, reflecting the local demography, can be dominated by Muslim members.

\section{The pros and cons of Perda Sharia}

During the process of the implementation of perda sharia, there were intense debate among the proponent and the contra groups. From this research found out that there are at least three arguments from the proponents of implementing perda sharia. The first is that the majority population of Indonesia is Muslim and the pre-colonial Muslim Kingdoms in Indonesia implemented sharia law, thus they argued that it was legitimate to implement perda sharia, as it is claimed, they represented the opinion of the majority population (Nunding Ram, Interview 3 June 2008). The second is that Perda Sharia will not create problems, due to the fact that its regulations are drafted openly and enacted by a democratically elected provincial or district legislature. The third was under regional autonomy Law, it is legitimate for a provincial and local government to implement regulations that try to resolve social problems and maintain public order. Thus, Indonesia's legal-political system, indirectly, allows the implementation of Perda Sharia, because the implementation of Perda Sharia in many districts in Indonesia was intentionally designed to avoid conflict with national laws. The provision in article 7 of Law No. 22/1999 stipulated that religious affairs do not come under the authority of the district governments, but rather under the central government. To resolve this, the regulations emphasised methods and measures to establish public order within the society, rather than appealing to Islamic sharia itself. Besides, district governments avoid using the term Sharia as a name of a regulation, but instead, they framed the regulations in terms of upholding 'morality and order' (Satriyo 2003). This means that those regulations cannot be annulled by the central government. Nevertheless, none of the Perda Sharia has been annulled. 
In contrast to the supporters, the opponents opposed the implementation of Perda Sharia because three reasons. The first is the Perda Sharia clash with the constitutional guarantee of religious freedom for all citizens to practice their religion according to their own beliefs. Second is that the Perda Sharia clashed with the national law. Although the supporters argued that Perda Sharia is not regulating religious affairs but rather morality and public order, however the motivation and the justification of the regulations were religious. Third was the content of the regulations, many of which are already in the penal code, such as regulations on gambling, prostitution, and alcohol consumption, so additional regulation would be unnecessary. Fourth, although the regulations were introduced by democratically elected legislatures, they were not acceptable because the regulations violate minority rights by discriminating against non-Muslim citizens (Kamil \& Bamualim 2007).

Furthermore, this research also found that the Perda Sharia legislation was not enacted democratically. Although it followed the formal procedures such as meeting and hearing, however, all of the meetings and hearings did not involve the broader groups by only inviting the supportive groups and excluding groups that opposed the proposed regulations (interview with Susan, women activist in Cianjur, and Yudi, LBH activist in Cianjur, 1998). In addition, the objections of the opposing groups and political parties were not considered at all. For instance in Cianjur, PDI-P decided to walk out and leave the meeting as their objections were not considered. And later the party sent a letter of objection to the minister of home affairs, however this did not result in anything. Iwan, the PDI-P (Partai Demokrasi Indonesia-Perjuangan-Indonesian Democratic Party of Struggle) member, who was also actively involved in the process of legalization of Perda Sharia in Cianjur, related that his party tried to lobby the provincial DPRD and DPR in Jakarta as well as the ministry of home affairs, arguing that the proposed Perda Sharia was in conflict with constitution. However, according to Iwan, the minister did not respond to their objection. This is because the minister, according to Iwan, did not have a vision and was not loyal to the Indonesian state (NKRI-Negara Kesatuan Republik Indonesia) and UUD 45; besides there was very strong pressure for not annulling such regulations (Iwan, interview 28 February 2008)

The debate about the implementation of Perda Sharia however, is not only among the Islamic groups, NGOs and Islamic organisation but also among the members of parliament (DPR). On 13 June 2006, 56 members of DPR signed a petition. The petition was initiated by Partai Damai Sejahtera (PDS-Prosperous Peace Party) Partai Demokrasi Indonesia Perjuangan (PDI-PIndonesian Democratic Party) According to Constan Ponggawa (Suara Pembaruan 2006) the members of DPR from PDS. the objective of the petition was to assure that the regulations were in accordance with: first, the principle of good governance in terms of the decision making process; second, did not contravene Law No 10/2004 on Formulation of Legislation (UU No 10 Tahun 2004 tentang pembentukan peraturan perundang-undangan) and Law No. 32/2004 on Regional Autonomy; and third, demanded that the Minister of Home Affairs evaluate whether the regulations were in accordance with the constitution or not. If they were not, the minister has to revoke the regulations. A day after the petition by 56 DPR members, several members of DPR opposed the petition by proposing a 'Contra Memorandum". The memorandum was initiated by Patrialis Akbar, from PAN (Partai Amanat National-National Mandatory Party), Lukman Hakim Saefuddin from PPP (Partai Persatuan Pembangunan-Development Unity Party) and Mutammimul Ula from PKS (Partai Keadilan Sejahtera-Prosperous Justice Party) (Suara Pembaruan 2006). The aim of this memorandum was to support the implementation of Perda Sharia and the regulation on Anti Maksiat (anti immoral acts). It was claimed that the memorandum was signed by 134 members of DPR (Alim 2010). Some parliament members who previously signed the petition withdrew their support including some members from GOLKAR because of some 'pressure' 
among other Muslim parliamentary members by labelling the supporters of the petition as not devout Muslims and supporters of pornography (Suara Pembaruan 2006).

It seems that there is a paradox in political Islam in Indonesia where, despite the very strong demand to implement Sharia, any endeavours to implement it at national level have always failed due to strong objections from opposing groups, which included many Muslims. Yet, the opponents have never succeeded with a judicial review to revoke any Islamic influenced regulations (Perda Sharia). There are some explanations for this paradox: the first is that the implementation of Perda Sharia is still debatable whether it is categorized as an Islamic regulation or not, as there are many regulations such as on gambling and prostitution which were not considered merely Islamic due to many other [non Islamic] countries also regulating these matters. Thus, the opponents did not have very strong arguments to revoke those regulations. The second is that the process of the implementation of Perda Sharia in many districts was strongly contested and was a long, drawn out and energy sapping process; hence any efforts to annul or revoke the regulations would again consume time and energy. Some of the opponents were prepared to see the regulations formally and symbolically implemented, but is not fully enforced.

The third, many groups and political parties did not have a clearly articulated policy on the implementation of Perda Sharia stand. And in many occasions, political leaders often makes public statements, either support or against the regulations to attract public attention (Bush 2008a, p. 175). Furthermore, some of the largest the political parties such as GOLKAR, PKB as well as the most influential Muslim organisatons, NU and Muhammadiyah, were opposed to the formalisation of Sharia at national level, however at the regional level, the branches of the NU and Muhammadiyah supported the implementation of Perda sharia, and in some extent initiated it, as will be further discussed in article 4. The fourth explanation is that, the introduction of Perda Sharia at the national level was different from the regional level. At the regional level, in most cases, the implementation of (perda) sharia was usually one of a number of issues debated during the Pilkada campaign for Bupati and was used by the candidates to mobilise support. The supporters of Perda Sharia utilised the pilkada as a political platform to advance the issue at the national level. Thus, Sharia at national level was mainly motivated by religious piety while at regional level there was a more short term political agenda (McLeod \& Maclntyre 2007, p. 127; Salim, A. 2007). The fifth explanation is that, the political dynamics at national level was different compared with the regional level. The political constellation in a region might tend to support the implementation of Perda sharia, hence if their parties or groups did not support it, their organisation would be left behind. Therefore, the political parties and Islamic groups that oppose sharia at national level would not automatically oppose perda sharia at the regional level to secure their political interest. Apart from that, change at the national level involved constitutional change of the ideology of the state-whereas, on the surface, perda sharia sought to regulate specific aspects of local societiespreventing prostitution and gambling and the consumption of alcohol.

Therefore, many saw that regional autonomy is the only chance to implement Perda Sharia since several attempts to implement Sharia law at national level had failed. This is because since the implementation of the regional autonomy law, the central government has less control of the regional government, especially with a growing number of provinces and districts that make it more difficult for the central government to supervise and to review the development of new regulations which might clash with higher law. Since then, the regional governments have greater power and authority to manage and govern their regions. To some extent, the regional governments manipulate the regional autonomy law for its own political advantage. In addition, political pressure from Islamic groups and political parties means the central government has 
never revoked the Perda Sharia through successful judicial review, although there has been lobbying from opponent groups for this process to be used.

Nevertheless, regional autonomy and the political reforms of the post Soeharto period have encouraged the emergence of local Islamic groups, who have been able to use this political space to advance the perda sharia agenda. These groups have campaigned for local governments and legislatures (DPRDs) to implement Perda Sharia. For example, in Cianjur, an organization which most activities raids cafe and restaurant and reduce immorality, GARIS (Gerakan Reformis IslamMovement of Islamic Reform) has sought to pressure the parliament and the candidates to support Perda Sharia. Likewise in Bulukumba, the KPPSI promoted and fully supported the implementation of perda sharia.

In the elections for both local legislatures and for heads of local governments (PIKADA) the implementation of Perda Sharia has been one of the campaign issues that candidates have used to mobilize support among the predominantly Muslim populations. According to Ahmad Suaedy (2006), some Perda Sharia were implemented merely to further the short term political agendas of the incumbent governors or heads of district (Bupati) to improve their chances for re-election. This research also found that the issue of sharia was often utilized to enhance the good image of the government and increase public trust in the government and the legislature, and that the introduction of Perda Sharia was often an investment by the Bupati and political parties in achieving success in the next local elections. There will further discussion on how the issue of sharia was used in the campaign in article 6 about Pilkada (pemilihan Kepala Daerah-the election for the head of district).

\section{The Politics of Nomenclature}

According to the former chairman of NU, Hasyim Muzadi (2006), the implementation of some regulations on Anti maksiat (anti immoral) such as banning gambling and banning prostitution were simply to complement the KUHP (Kitab Undang-Undang Hukum Pidana-Book of Penal Law), however by giving the name as a Perda Sharia there was the risk that such regulations might encourage anti Islamic sentiment (Hasyim Muzadi 2006). Similiarly, Jusuf Kalla (Antara News 2007), the former vice President and the former chair of GOLKAR, argued that regulations banning prostitution, gambling and alcohol consumption could not be categorised as Perda sharia. Hidayat Nurwahid, former vice chairman of the People's Representative Assembly (MPR) from PKS stated that demand to implement sharia, should not refer to Islamic Law, but instead of focus on moral enhancement (Bush 2008b)

Hasyim Muzadi and Jusuf Kalla's opinions illustrate just how sensitive an issue perda sharia is. It is considered as a 'sacred' word that evokes memories of the controversies surrounding the failed attempts to change the constitution, Given the division of powers between central government and district government, the district governments that have implemented Sharia-influenced regional regulations often prefer to not use the word 'sharia', so as not to attract the attention of the central government.

Slamet Effendi Yusuf, a former Golkar Party politician who is currently a vice chairman of NU, argues that regional regulations should not be regarded as sharia regulations if the regulations do not use Alquran or hadith as a source of reference. However, there are at least four indications that some regulations could be categorised as sharia Influenced-regional regulation: the first, the regulations are made based on moral or religious motivation such as the regulation on prostitution, alcohol consumption and gambling. Although these types of regulations are common in non- 
Muslim countries, such as Australia, however, these regulations in Australia were not made based on religious or moral motivation but rather to address health and social problems. The second, regulations are adapted from the part of Islamic ritual, such as regulation 'jumat khusuk' (Friday solemn). 'Sholat jum'at berjamaah' (conduct Friday prayer together) are compulsory for all male adult Muslim, however regulations banning people to do any activities other than jum'at prayer on Friday has never regulated in Islamic jurisprudence. In addition, fasting during Ramadan is compulsory for all Muslim adults, however closing cafés and restaurants during the month of Ramadhan have never been regulated in Islamic teaching. The third, enhancing Islamic skills such as obligations to read Qur'an for couples wanting to marry. In Islam, all Muslims are obligated to study, but not only the Quran. The fourth is regulation on expressing the Islamic symbol such as regulation on jilbab, Muslim clothes for staff government uniform. However, from these regulations the most significant relates to the jilbab, because the jilbab is a most visible symbol of Islam and has become a core issue in political Islam. This will be discussed further in article 9 .

Some researchers have identified three variants of Perda sharia: firstly, those that seek to eradicate moral and social problems such as prostitution, drinking alcohol and gambling; secondly those that enforce ritual observances among Muslims such as reading the Qur'an, attendance at Friday prayers and fasting during Ramadan, and, thirdly, those that seek to govern the way people dress in the public sphere, especially in relation to head-veiling for the women (Azra \& Salim 2003; Bush 2008b; Candraningrum 2006). However, there are still problems of the appropriate terminology because of its politics of nomenclature. In districts governments use a variety of nomenclature for three types of Perda Sharia. In general, residents of these districts will be reluctant to use the term perda sharia, especially the government officials, because they are aware that term 'sharia' is too sensitive and they understand that religious matters is not under the authority of district governments. Outsiders tend to be more flexible. Here I tried to categories the way how people called Perda Sharia into two groups, residents and outsiders:

1. The outsiders who support the perda are usually prepared to use the nomenclature I Perda Sharia and are often in favour of implementation in other districts. These outsiders include hardliners such as Majelis Mujahidin Indonesia, Hizbu Tahrir Indonesia. However, other outsiders who supported Perda Sharia also reluctantly calls it as a Perda Sharia because they do not want to be seen supporting unconstitutional regulations. These outsiders include members of Islamic political parties such as PKS, PBB and PPP. Whereas, opponents of these regulations will use Perda Sharia in order to emphasize their view that the regulations are in contravention of the constitution. These outsiders are usually members of secular organisations and NGOs. Some refer to the regulations as 'unconstitutional perda', so as to avoid politicisation of Sharia andlslam. This group is Islamic NGOs.

2. Residents opposed to the regulations tend to use the term Perda Sharia. Whereas, residents who support the regulations prefer to avoid 'Sharia', instead they use other names, such as perda keagamaan, perda bernuansa Islam. They call it as other than Perda Sharia because they are aware of the constitution question;

The distinction between residents and outsider is very important because during the research, the term of 'orang luar', outsider and 'orang sini/orang dalam' or resident was often mentioned by the informants when they discussed Perda Sharia. Apart from that, the research also found that the residents who have made contact with outsiders including organisations, NGOs, mostly have more open opinion and more critical of Sharia and its implementation in Perda Sharia. The outsiders from formalist Islamic groups are more open to use Perda sharia. 
The way in which the supporters name Perda Sharia is also different. Those who support Perda Sharia for idealistic reasons, many of whom are members of Islamic organisations, prefer Perda Sharia because they believe if there are more people using (the name) 'sharia' it means Sharia would be more popular and accepted more easily. There are also political pragmatists, who often hold positions in the government or legislature, who are aware of the political and constitutional complexities and sensitivities and will avoid using the term Perda Sharia so as not to jeopardize their position in the government.

\section{CONCLUSION}

The Law No. 22, 1999 of the Regional autonomy is aimed to devolve central government authorities to local governments in all government administrative sectors, except for security and defense, foreign policy, monetary and fiscal matters, justice, and religious affairs (Usman 2002). This Law is not only giving more authority for the local government to manage their resources but also open the opportunity for the Islamic groups and the proponents of sharia to propose and implement sharia which they have struggled since early day of Indonesian independence but have always failed. Although it is obviously stipulated in the Law that religious affairs is not the authority of the local government, nevertheless, since the central government passed this Law, many districts in Indonesia implement and propose for the implementation of syariah-influenced regional regulation (perda sharia). Therefore, the implementation of the Perda Sharia is one of the unintended consequences of the Regional Autonomy Law and it is worth noting that the implementation of Perda sharia is only possible after the government pass the Regional Autonomy Law.

Although many districts have been implementing the Perda Sharia, none of the regulations have been annulled by the central government. This article argues that the issue of sharia has shifted from demanding to incorporate sharia into national constitution to proposing to implement Sharia in the regions. Bottom line of that, the issue of sharia has changed from the national phenomena to be more local. 


\section{References:}

Alim, M. (2010). Perda Bernuansa Syariah Dan Hubungannya Dengan Konstitusi Hukum, vol. 17, no. 1, pp. 119-42.

Antara News. (2007). Wapres : Perda Syariat Islam Rendahkan Derajat Islam). ANTARA News.

Ardiansyah, A, Syafi'i, S \& Anthony. (2006). Risau Beleid Bilah Bambu. Gatra.

Asi, RA. (2007). Sulawesi: aspirations of local Muslims, Rajaratnam School of International Studies.

Aspinall, E \& Fealy, G. (2003). Local power and politics in Indonesia: decentralisation \& democratisation, Institute of Southeast Asian Studies.

Azra, A \& Salim, A. (2003). Shari'a and politics in modern Indonesia, ISEAS series on Islam. Singapore : Institute of Southeast Asian Studies.

Boland, BJ. (1982). The struggle of Islam in modern Indonesia, Slightly rev. reprint. edn, Nijhoff, The Hague.

Bruinessen, Mv. (1996a). Islamic state or state Islam? Fifty years of state-Islam relations in Indonesia, in Ingrid Wessel (Hrsg.) (ed.), Indonesien am Ende des 20, Abera-Verlag, Hamburg, pp. 19-34.

---- (1996b). Islamic state or state Islam? Fifty years of state-Islam relations in Indonesia, in IW (Hrsg.) (ed.), Indonesien am Ende des 20. Jahrhunderts, Hamburg, Hamburg: AberaVerlag, pp. 19-34.

Bush, R. (2008a). Regional Sharia Regulations in Indonesia: Anomaly or Symptom?, in G Fealy \& $S$ White (eds). Expressing Islam: Religious Life and Politics in Indonesia. Singapore : Institute of Southeast Asian Studies, pp. 174-91.

(2008b). Regional Sharia Regulations in Indonesia: Anomaly or Symptom?, in G Fealy \& S White (eds), Expressing Islam: Religious Life and Politics in Indonesia. Singapore: Institute of Southeast Asian Studies. pp. 174-91.

Candraningrum, D. (2006). Perda Sharia and the Indonesian Women's Critical Perspectives paper presented to Neue Willkuer gegen Frauen in Indonesien: Kontroversen um die Umsetzung der Regionale Scharia-Gesetze Perda Syariah (New Arbitrary against Women in Indonesia: Perda Sharia and Women's Rights), ÜBERSEEMUSEUM Bremen, Germany, 11 November 2006.

Ellis, A .(2007). Indonesia's Constitutional Change Reviewed, in RH McLeod \& RM Andrew Maclntyre McLeod (eds), Indonesia : democracy and the promise of good governance. Singapore: Institute of Southeast Asian Studies, vol. 24.

Erawan, IkP. (2007). Tracing the Progress of Local Governments since Decentralisation. in RH McLeod \& A Maclntyre (eds), Indonesia Democracy and the Promise of Good. Singapore: Institute of Southeast Asian Studies, ISEAS, pp. 55-69. 
Fealy, G . (2005). Islamisation and politics in Southeast Asia: The contrasting cases of Malaysia and Indonesia, in $\mathrm{AH}$ Johns \& N Lahoud (eds), Islam in world politics. London : RoutledgeCurzon, p. 152.

Halim,W. (2005). Shariah Implementation in South Sulawesi: An Analysis of the KPPSI Movement Future Islam.

Hasan, N. (2008). Reformasi, Religious Diversity, and Islamic Radicalism after Suharto, vol. 1. The Netherlands : Indonesian Social Sciences and Humanities.

Hefner, RW. (1993). Islam, State, and Civil Society: ICMI and the Struggle for the Indonesian Middle Class . Indonesia, vol. 56, no. April, pp. 1-35.

Hooker, MB. (2003). Indonesian Islam : social change through contemporary fatawa, Southeast Asia publications series., Asian Studies Association of Australia in association with Allen \& Unwin, Crows Nest, N.S.W.

Hosen, N. (2004). Behind the Scenes: Fatwas of Majelis Ulama Indonesia (1975-1998), Journal of Islamic Studies, vol. 15, no. 2, pp. 147-79.

Ichwan, MN. (2005). Ulama, State and Politics: Majelis Ulama Indonesia After Suharto, Islamic Law and Society, vol. 15, no. 1, pp. $45-72$.

Ismail, F. (1995). Islam, Politics and Ideology in Indonesia: a Study of the Process of Muslim Acceptance of the Pancasila, dissertation thesis, McGill University.

Kamil, S \& Bamualim, CS (eds). (2007). Syariah Islam dan HAM: Dampak Perda Syariah terhadap Kebebasan Sipil, Hak-hak Perempuan, dan Non-Muslim, Center for the Study of Religion and Culture. Jakarta : Universitas Islam Negeri Jakarta.

Kementrian Agama Republik Indonesia. (11 Mei 2011). Menteri Agama dari masa ke masa, Kementrian Agama Republik Indonesia.

http://www.kemenag.go.id/index.php?a=artikel\&id2=menag\%3E.

Liddle, RW. (1996). 'The Islamic Turn in Indonesia: A Political Explanation', Journal of Asian Studies, vol. 55, no. 3, pp. 613-34.

1996 Leadership and culture in Indonesian politics, Asian Studies Association of Australia in association with Allen \& Unwin, Sydney.

McLeod, RH \& Maclntyre, A (eds). (2007). Indonesia Democracy and the Promise of Good Governance. Singapore : Institute of Southeast Asian Studies, ISEAS.

Miller, MA. (2006). 'What's Special about Special Autonomy in Aceh?', in A Reid (ed.), Verandah of Violence: the background to Aceh Problem. Singapore: the National University of Singapore, NUS Press, p. 423.

2008, Rebellion and Reform in Indonesia: Jakarta's Security and Autonomy Polices in Aceh, Taylor \& Francis. 
Muzadi, Hasyim. (2006). Hasyim Muzadi: Perda Syariah Tidak Diperlukan, Gatra, 16 June 2006.

Möller, A. (2005). Ramadan in Java: the Joy and Jihad of Ritual Fasting, Almqvist \& Wiksell International, Stockholm.

Mudzakkar, AAQ. (2010). Amir Majelis Komite Perjuangan Penegakan Syariat Islam, Abdul Aziz Qahhar Mudzakkar: Gandeng Bupati Wujudkan Gerakan Kultural', Fajar Makassar, Friday, 05 March 2010.

Mudzhar, MA. (1993). Fatwa-Fatwa Majelis Ulama Indonesia: Sebuah Studi tentang Pemikiran Hukum Islam di Indonesia 1975-1988, INIS, Jakarta.

Mujani, S. (2007). Muslim demokrat: Islam, budaya demokrasi, dan partisipasi politik di Indonesia pasca Orde Baru, Gramedia Pustaka Utama.

Mujiburrahman. (2006). Feeling Threatened: Muslim-Christian Relations in Indonesia's New Order, Amsterdam University Press.

Porter, DJ. (2002). Managing politics and Islam in Indonesia, RoutledgeCurzon, Abingdon, Oxon, New York.

Pringle, R. (2010). Understanding Islam in Indonesia: Politics and Diversity. Honolulu : University of Hawai Press.

Ricklefs, MC. (2008). A History of Modern Indonesia since c. 1200, 4 edn, Wales: Palgrave, Stanford University Press, Stanford.

Riddell, PG. (2005). 'Islamization, Creeping Shari'a, and Varied Responses in Indonesia', in P Marshall (ed.), Radical Islam's Rules: The Worldwide Spread of Extreme Shari'a Law, Rowman \& Littlefield, Lanham.

Salim, A. (2007). 'Muslim Politics in Indonesia's Democratisation: The Religious Majority and The Rights of Minorities in The Post-New Order Era', in RH McLeod \& A Maclntyre (eds), Indonesia: Democracy and the Promise of Good Governance. Singapore: Institute of Southeast Asian studies, pp. 115-37.

Salim, A \& Azra, A (eds). (2003a). Shari'a and politics in modern Indonesia, ISEAS series on Islam. Singapore: Institute of Southeast Asian Studies.

(eds) (2003b), Shari'a and politics in modern Indonesia, Institute of Southeast Asian Studies, Singapore.

Santosa, JC. (1996). Modernization, utopia and the rise of Islamic radicalism in Indonesia. dissertation thesis, Boston University.

Satriyo, HA. (2003). Decentralisation and Women in Indonesia: One Step Back, Two Steps Forward', in E Aspinall \& G Fealy (eds), Local power and politics in Indonesia. Decentralisation and democratization. Indonesia update series. Research School of Pacific and Asian Studies. Australian National University. Singapore: Institute of Southeast Asian Studies, pp. 207-29. 
Suaedy, A. (9 January 2008). Perda SI Tidak Menyelesaikan Masalah Sosial (Syariah by Law do not alleviate social problems), wahidinstitute.org http://www.wahidinstitute.org/Program/Detail?id=205/hl=id/Perda_SI_Tidak_Menyelesaika n_Masalah_Sosial\%3E.

Suara Pembaruan. (2006). Petisi Pencabutan Perda Jalan Terus, Suara Pembaruan, 22 June 2006.

Turner, M, Podger, O, Sumardjono, M \& Tirthayasa, WK, Decentralisation in Indonesia : redesigning the state Asia Pacific Press, Canberra.

(2003b), Decentralisation in Indonesia: Redesigning the State, Asia Pacific Press, Canberra.

Usman, S. (2002). Regional autonomy in Indonesia: field experiences and emerging challenges, paper presented to The 4th IRSA International Conference, Bali.

van Bruinessen, M. (1996). 'Islamic State or State Islam? Fifty Years of State-Islam Relations in Indonesia', Indonesien am Ende des 20. Jahrhunderts, no. 19-34, pp. 19-34.

(2002). 'Genealogies of Islamic radicalism in post-Suharto Indonesia', South East Asia Research, vol. 10, no. 2, pp. 117-54. 